\title{
GENETIC AND PHENOTYPIC TRENDS FOR TEST DAY MILK, FAT AND PROTIN YIELDS APPLYING RANDOM REGRESSION MODEL IN EGYPTIAN BUFFALOES
}

\author{
A.M.S. Amin ${ }^{1}$, M.H. Khalil ${ }^{2}$, K.A. Mourad ${ }^{1}$, E.A. Afifi ${ }^{2}$ and M.K. Ibrahim ${ }^{2}$ \\ ${ }^{1}$ Animal Production Research Institute, Buffalo Breeding Research Department, Dokki, Giza, Egypt. \\ ${ }^{2}$ Department of Animal Production, Faculty of Agriculture at Moshtohor, Benha University, Egypt. \\ Corresponding author: Email: maher.khalil@fagr.bu.edu.eg
}

\section{SUMMARY}

The aim of this study was to detect genetic and phenotypic trends for test day milk, fat and protein yields in Egyptian buffalo applying the random regression model (RRM) and determining the genetic and phenotypic trend. Data of 4971 test days (TD) milk yield traits were recorded for 691 Egyptian buffalo cows, daughters of 120 sires and 532 dams from four herds belonging to the Animal Production Research Institute, Egypt. Ten-month classes of lactation days were considered for the test-day yields. The model included the random effects of direct additive genetic, permanent environment and error, while the fixed effects were herd-test day, year and season of calving and parity as well as days in milk as a covariable, which was modeled by orthogonal Legendre polynomials. The additive genetic variance estimates at first test day for milk, fat and protein yields were respectively $0.035 \mathrm{~kg}, 2.26 \mathrm{~g}$, $0.80 \mathrm{~g}$, increased until the fourth $(0.807 \mathrm{~kg}, 30.52 \mathrm{~g}, 12.52 \mathrm{~g})$, decreased thereafter, reaching the lowest value at the ninth test day for milk and protein yields $(0.238 \mathrm{~kg}, 0.97 \mathrm{~g})$ and at the tenth test day for fat yield (7.28g). Heritability estimated at first test day was 0.05, increased until the fourth test day $(0.30)$, and decreased thereafter and reached the lowest value at the tenth test day (0.06). The highest heritabilities were found to be 0.29 and 0.31 for fourth test day in fat and protein yields, respectively. The range in phenotypic values change decreased from 7.99 to $5.66 \mathrm{~kg}, 53.37$ to $35.07 \mathrm{~g}$ and 30.86 to $21.54 \mathrm{~g}$, while the respective genetic values change increased from -0.22 to $0.17 \mathrm{~kg}$, -1.41 to $1.36 \mathrm{~g}$ and 0.82 to $0.70 \mathrm{~g}$ for milk, fat and protein yields, respectively. The genetic trends were slightly positive for all traits indicating that the selection program performs correctly. For all traits, the phenotypic trends showing deteriorating trends indicating the presence of some environmental inadequacies especially for nutritional level.

Keywords: Egyptian buffalo, test day milk, fat and protein yields, random regression model, genetic and phenotypic trends

\section{INTRODUCTION}

Milk yield in the day of record is defined as the sum of milk yield of a buffalo cow during 24 hours. Test day models allow for better modeling because it is possible to take into account effects specific to the day at recording (test day). With this method, the environmental effects are better modeled (Ptak and Schaeffer, 1993), and the genetic parameter estimates are expected to be more accurate (Swalve, 2000). These methods have been used in the genetic evaluation for milk yield in many countries (INTERBULL, 2009). By using the test day milk yield (TDMY) parameter, there is no need to extend the lactation period for animals to reach 305 lactation days, by means of adjusting factors. Different methods have been proposed to estimate the (co) variance structure among TD. Meyer (1998) clarified that the best method of dealing with longitudinal traits measured over a trajectory is to fit a set of random coefficients to describe the covariance structure along this trajectory. Kirkpatrick et al. (1990) added that random regression models (RRMs) facilitate more accurate modeling of the variancecovariance structure over a given trajectory. In Murrah buffalo, Aspilcueta-Borquis et al. (2012) estimated the additive genetic and permanent environment variances for milk, fat, and protein yields, using single trait RRM.

It is imperative to follow the results of an animal breeding program to assess its development as well as to make effective adjustments. One way of evaluating an animal breeding plan is to determine the phenotypic and genetic trends. Thus, the study of genetic trend in a population is a significant element in monitoring of the selection, since it corresponds to the observed changes in the average breeding values of animals studied for a specific trait during the selection work (Potocnik et al., 2007).

The objectives of the present study were: (1) to investigate improvement possibilities through the application of RRM for TD milk, fat and protein yields in Egyptian buffalo and (2) detect genetic and phenotypic trends. 


\section{MATERIAL AND METHODS}

Dataset:

Data used in this study were collected at monthly intervals over the period from 1999 through 2009 from four buffalo experimental herds (El-Nattafe El-Gadid, El-Nattafe ElKadim, Mahalet Mousa and El-Gemmiza) belonging to the Animal Production Research Institute (APRI), Ministry of Agriculture and Land Reclamation, Egypt. Test day (TD) records for milk, fat and protein yields were measured following an alternative am-pm monthly recording scheme. Milking was practiced twice a day at 7 am and 4 pm throughout the lactation period. Fat and protein yields were measured by the automated method of infrared absorption spectrophotometry (Milk-o-Scan; Foss Electric, Hilleryd, Denmark) at the Dairy Services Unit, Animal Production Research Institute, Sakha, Kafr El-Sheikh Governorate. Buffalo cows with less than four TD records per lactation were excluded from the data set, while the maximum number of test day records per lactation was 10 records. Moreover, upnormal phenotypic values of daily milk yield, fat and protein yield were removed from the dataset. The data are normally distributed and all known relationships among the individuals were considered in the animal model. The structure of the data analyzed is shown in Table (1).

Table 1. Structure of test day (TD) data analyzed in Egyptian buffaloes

\begin{tabular}{lc}
\hline Item & Data \\
\hline No. of sires & 120 \\
No. of dams & 532 \\
No. of cows with records & 691 \\
No. of base animals & 469 \\
No of non-base animals & 684 \\
Total number of animals & 1153 \\
Total number of lactation records & 4971 \\
\hline
\end{tabular}

\section{Statistical analysis:}

The model of the analysis included the fixed effects of herd test day (40 levels), year (10 years) and season of calving (two seasons) and parity (five parities) as well as days in milk as a

$$
Y_{i j k l}=H T D_{i}+\sum_{m=1}^{4} \beta_{k m} Z_{j l m}+\sum_{m=1}^{4} \alpha_{j m} Z_{j l m}+P_{j}+e_{i j k l}
$$

where: $\mathrm{Y}_{\mathrm{ijkl}}$ is the record 1on trait within lactation made on HTD subclass $\mathrm{i}$ for the $\mathrm{j}^{\text {th }}$ buffalo cow belonging to $\mathrm{k}^{\text {th }}$ subclass ( $\mathrm{k}$ ranged from 1 to 10 starting with $\mathrm{k}=1$ and increased by 1 every 30 days thereafter along the trajectory from 4 to $304-d$ ); HTD $_{i}$ is the fixed effect of herd test day, $P_{j}=$ random effect of permanent environment associated with all TD yields of the $\mathrm{j}^{\text {th }}$ buffalo; $\beta_{\mathrm{km}}$ and $\alpha_{\mathrm{jm}}=$ fixed and random regression coefficient, and $\mathrm{e}_{\mathrm{ijkl}}=$ random residual effect associated with $\mathrm{Y}_{\mathrm{ijk}}$.

The VCE6 program applying the Random Regression Model (RRM) was used to analyze the data using the Legendre polynomials method

$$
\left(\begin{array}{l}
a \\
p \\
e
\end{array}\right) \sim N(0, V) \text { where, } \quad V=V a r
$$

where $\mathrm{G}$ and $\mathrm{P}$ are (co)variance matrix of additive genetic and permanent environment random regression coefficients, respectively; A is an additive genetic relationship matrix among the buffaloes; $\bigotimes$ is a Kronecker product covariable. Variance-covariance components were estimated by REML using the computer package VCE6 (Groeneveld, et al., 2010).The animal model was:

(Kirkpatrick et al., 1990).The general RRM can be represented in matrix notation as:

$$
\mathrm{Y}=\mathrm{Xb}+\mathrm{Za}+\mathrm{Wp}+\mathrm{e}
$$

Where, $\mathrm{Y}=$ vector of observations on animal; $\mathrm{b}=$ vector of the fixed effects; $a=$ vector of solutions for additive genetic random coefficients; $p=$ vector of solutions for permanent environmental random coefficients; $\mathrm{e}=$ vector of $\mathrm{N}$ different residuals; $\mathrm{X}, \mathrm{Z}$, and $\mathrm{W}=$ incidence matrices for fixed and random genetic and permanent environmental random effects, respectively. The assumptions with respect to the components of the model were (Jamrozik and Schaeffer, 1997; Schaeffer, 2004):

$$
\left(\begin{array}{l}
a \\
p \\
e
\end{array}\right)=\left(\begin{array}{ccc}
G \otimes A & 0 & 0 \\
0 & I \sigma_{p}^{2} & 0 \\
0 & 0 & R
\end{array}\right)
$$

function; $\mathrm{I}$ is identity matrix and $\mathrm{R}$ is the diagonal matrix of temporary environmental variances. The mixed model equations for this model would be: 


$$
\begin{gathered}
V=\left(\begin{array}{ccc}
X^{\prime} X & X^{\prime} Z & X^{\prime} W \\
Z^{\prime} X & Z^{\prime} Z+G^{-1} \otimes A-1 & Z^{\prime} W \\
W^{\prime} X & W^{\prime} Z & W^{\prime} W+I \otimes P^{-1}
\end{array}\right)\left(\begin{array}{l}
b \\
a \\
p
\end{array}\right)=\left(\begin{array}{c}
X^{\prime} Y \\
Z^{\prime} Y \\
W^{\prime} Y
\end{array}\right) \\
E\left[\begin{array}{c}
y \\
a \\
p \\
e
\end{array}\right]
\end{gathered}
$$

Where $k_{a}$ and $k_{p}$ are the genetic and permanent environmental covariance matrices between random regression coefficients, respectively. A is the additive genetic relationship matrix; $\mathrm{I}$ is an identity matrix, and $\mathrm{R}$ represents a diagonal matrix containing the residual variances.

Orthogonal polynomials of standardized units of time have been recommended as covariables (Kirkpatrick et al., 1990). Orthogonal polynomials have computational advantages. The primary general advantage is the reduced correlations among the estimated coefficients. A

$$
G=\left(\begin{array}{llll}
1 & t i & t i^{2} & \ldots
\end{array}\right) K a\left[\begin{array}{c}
1 \\
t j \\
t j^{2} \\
\ldots . .
\end{array}\right]
$$

When the structure of residual variance was fitted by variance function, the variances were estimated by:

$$
V_{e_{i}}^{2}=V_{e_{0}}^{2}\left(1+\sum_{r=1}^{q} \beta_{r} t_{i j}^{r}\right),
$$

Heritabilities $\left(\mathrm{h}^{2}\right)$ are computed using the package of VCE6 as (Groeneveld et al., 2010):

$$
h^{2}=\frac{\sigma_{\mathrm{gi}}^{2}}{\sigma_{g i}^{2}+\sigma^{2} p i+\sigma^{2} e i}
$$

Where: $\sigma_{\text {gi }}^{2}$ is the additive genetic variance of the $i^{\text {th }} \mathrm{TD} ; \sigma_{\mathrm{pi}}^{2}$ is the permanent environmental variance and $\sigma_{\text {ei }}^{2}$ is the residual variance.

\section{Predicted breeding values:}

Buffaloes predicted breeding values (PBVs), predicted error variance (PEV) (i.e. standard errors, SE) and accuracies of predictions ( $\left.r_{a} \hat{a}\right)$ were estimated by REML using the computer package PEST (Groeneveld et al., 2001) for test day milk, fat and protein yields according to the following model:

$$
\mathrm{y}=\mathrm{Xb}+\mathrm{Za} \mathrm{a}+\mathrm{Zc} \mathrm{c}+\mathrm{e}
$$

where: $\mathrm{y}=$ Vector of observations, $\mathrm{X}=$ Incidence matrix relating fixed effects to $y, b=$ Vector of an overall mean and fixed effects (herd-test day, season of calving, parity and days in milk as a covariable), $\mathrm{Za}=$ Incidence matrix relating direct additive genetic effects to $\mathrm{y}, \mathrm{a}=$ Vector of random effect (direct additive genetic standardized unit of time, $t$, ranges from -1 to +1 , and is derived as

$$
t^{*}=\frac{2(t-t \min )}{t \max ^{-t} \min }-1
$$

Where " $t$ " is " $t_{\min }$ " is the lowest age and " $t_{\max }$ " is the highest age.

The genetic (G) and permanent environmental $(\mathrm{P})$ covariances between test-days were estimated using:

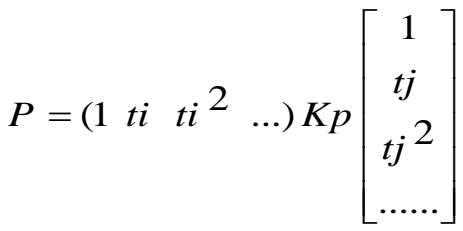

associated with the incidence matrix $\mathrm{Za}, \mathrm{Zc}=$ Incidence matrix for permanent environmental effect, $\mathrm{c}=$ Vector of permanent environmental effect associated with the incidence matrix $\mathrm{Zc}$ and $\mathrm{e}=$ Vector of random residual effects $\mathrm{N}(0$, $\mathrm{I} \sigma^{2}{ }_{\mathrm{e}}$ ); $\mathrm{I}$ is an identity matrix.

Solutions for equations of animals were computed from the pedigree file, one animal at a time for animals with records and animals without records (sires and dams). A diagonal element $\left(d_{t}\right)$ and an adjusted right-hand side $\left({ }^{y^{*}}{ }_{t}\right)$ were accumulated with each pedigree file record for the $\mathrm{t}^{\text {th }}$ animal. For animal with and without records, the formula used to estimate the PBV was (Kennedy, 1989):

$\mathrm{PBV}=\left[{ }_{\mathrm{t}}^{\mathrm{y}} / \mathrm{d}_{\mathrm{t}}\right]$

The predicted error variance (PEV) of predicted breeding values $\left(\mathrm{PBV}_{\mathrm{p}}\right)$ were estimated for each individual as: $P E V_{\mathrm{p}}=\mathrm{d}_{\mathrm{j}} \sigma_{\mathrm{e}}^{2}$ (Korsgaard $e t$ al., 2002); where $\mathrm{d}_{\mathrm{j}}$ and $\sigma_{\mathrm{e}}^{2}$ were defined before. The accuracy of PBV for each individual was estimated according to Henderson (1975) as:

$$
r_{A \hat{A}}=\sqrt{1+F_{j}-d_{j} \alpha_{a}}
$$

where ${ }^{r} A \hat{A}=$ the accuracy of prediction of the $i^{\text {th }}$ animal's breeding value; $F_{j}=$ inbreeding coefficient of animals (assumed equal to be zero); $d_{j}=$ the $j^{\text {th }}$ diagonal element of inverse of the appropriate block coefficient matrix; and $\alpha_{\mathrm{a}}=\sigma_{\mathrm{e}}^{2} / \sigma_{\mathrm{a}}^{2}$. 
Genetic and Phenotypic trends:

The phenotypic trend was measured as the regression of least squares means on year-testday. As stated before animal with records and without records breeding values were estimated using the theory of PEST (Groeneveld et al., 2001). Accordingly the genetic trend was measured by regressing the breeding values on year-test-day.

\section{RESULTS AND DISCUSSION}

Means:

The observed means, the standard deviations and the coefficients of variation for TD milk, fat and protein yields are shown in Table (2). The means for TDMY showed a lactation curve initializing with $5.19 \mathrm{~kg}$, followed by an increase in milk yield until the peak of the lactation, occurred in the third test-day $(8.47 \mathrm{~kg})$, and a decrease until the end of lactation with a production of $5.14 \mathrm{~kg}$ in the tenth test-day lactation. The means observed for fat and protein yields were showing the same trend as that for TDMY. The means for fat and protein yields are 33.45 and $20.42 g$, respectively, on the first test day, followed by an increase until the peak of lactation (54.21 and 32.29g) and decrease at the end of lactation (35.12 and 20.22g). Tonhati et al. (2008) for Murrah buffalo and Madad et al. (2013) for Iranian buffaloes reported similar results of milk means unlike the first test day. Aspilcueta-Borquis et al. (2010) in Murrah buffalo reported higher means of milk in the first test day and the milk yield decreased at the end of lactation. The authors reported the same result regarding fat and protein.

\section{Variances:}

Estimates of additive genetic, permanent environmental and phenotypic variances are presented in Figures (1), (2) and (3) for milk, fat and protein yields. The additive genetic variance estimates at first test day were $0.035 \mathrm{~kg}, 2.26 \mathrm{~g}$ and $0.80 \mathrm{~g}$, increased until the fourth test $(0.807 \mathrm{~kg}, 30.52 \mathrm{~g}$ and $12.52 \mathrm{~g})$ and decreased thereafter, reaching the lowest value at the ninth test day for milk and protein yields $(0.238 \mathrm{~kg}$ and $0.97 \mathrm{~g}$ ) and at the tenth test day for fat yield $(7.28 \mathrm{~g})$. Similar results have been reported by Silvestre et al. (2005) and Sesana et al. (2010) who working with dairy buffaloes.

Table 2. Number of observations, means, standard deviations (SD) and coefficients of variation (CV) for test day (TD) milk, fat and protein yields

\begin{tabular}{|c|c|c|c|c|c|c|c|c|c|c|}
\hline \multirow[b]{2}{*}{ TD } & \multirow[b]{2}{*}{$\begin{array}{l}\text { Number of } \\
\text { observation }\end{array}$} & \multicolumn{3}{|c|}{ Test day milk yield } & \multicolumn{3}{|c|}{ Test day fat yield } & \multicolumn{3}{|c|}{ Test day protein yield } \\
\hline & & $\begin{array}{c}\text { Mean } \\
(\mathrm{kg})\end{array}$ & $\begin{array}{l}\text { SD } \\
(k g)\end{array}$ & $\begin{array}{l}\text { CV } \\
(\%)\end{array}$ & $\begin{array}{c}\text { Mean } \\
(\mathrm{g})\end{array}$ & $\begin{array}{l}\text { SD } \\
(g)\end{array}$ & $\begin{array}{l}\text { CV } \\
(\%)\end{array}$ & $\begin{array}{c}\text { Mean } \\
(g)\end{array}$ & $\begin{array}{l}\text { SD } \\
(g)\end{array}$ & $\begin{array}{l}\text { CV } \\
(\%)\end{array}$ \\
\hline 1 & 693 & 5.19 & 1.02 & 19.6 & 33.45 & 7.99 & 23.9 & 20.42 & 4.32 & 21.2 \\
\hline 2 & 693 & 7.51 & 2.20 & 29.4 & 47.19 & 15.66 & 33.2 & 28.75 & 8.87 & 30.8 \\
\hline 3 & 693 & 8.47 & 2.42 & 28.5 & 54.21 & 17.22 & 31.8 & 32.29 & 9.39 & 29.1 \\
\hline 4 & 693 & 8.23 & 2.39 & 29.1 & 54.05 & 17.95 & 33.2 & 31.36 & 9.63 & 30.7 \\
\hline 5 & 664 & 7.51 & 2.33 & 31.1 & 49.67 & 16.92 & 34.1 & 28.69 & 9.09 & 31.7 \\
\hline 6 & 595 & 6.71 & 2.10 & 31.3 & 44.17 & 14.75 & 33.4 & 25.70 & 8.06 & 31.4 \\
\hline 7 & 454 & 6.10 & 1.89 & 31.0 & 40.78 & 13.73 & 33.7 & 23.26 & 6.92 & 29.7 \\
\hline 8 & 302 & 5.61 & 1.75 & 31.1 & 37.58 & 12.33 & 32.8 & 21.89 & 6.65 & 30.4 \\
\hline 9 & 141 & 5.42 & 1.63 & 30.0 & 36.48 & 11.29 & 30.9 & 21.32 & 6.69 & 31.4 \\
\hline 10 & 55 & 5.14 & 1.42 & 27.6 & 35.12 & 10.62 & 30.2 & 20.22 & 5.16 & 25.5 \\
\hline
\end{tabular}

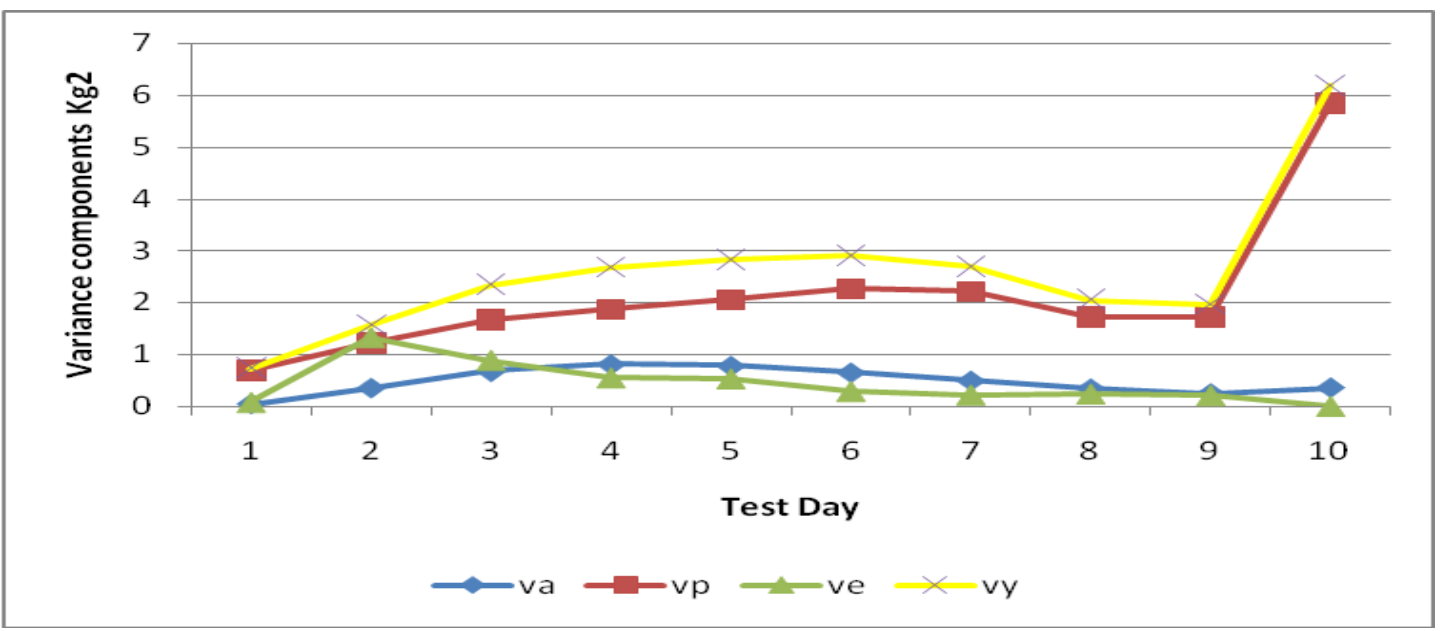

Fig. 1. Estimates of additive genetic (va), permanent environmental (vp), residual variances (ve) and phenotypic variances (vy) for test day milk yield $(\mathrm{kg})$ in Egyptian buffaloes 


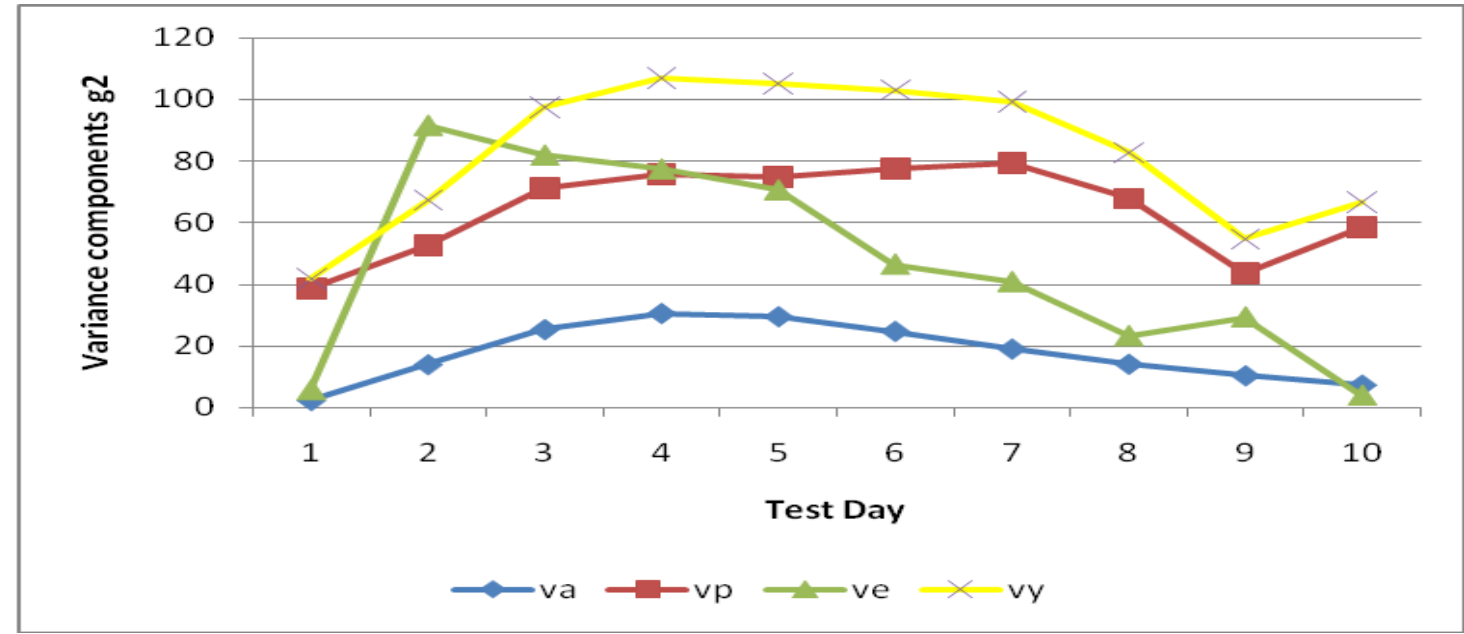

Fig. 2. Estimates of additive genetic (va), permanent environmental (vp), residual variances (ve) and phenotypic variances (vy) for test day fat yield $(g)$ in Egyptian buffaloes

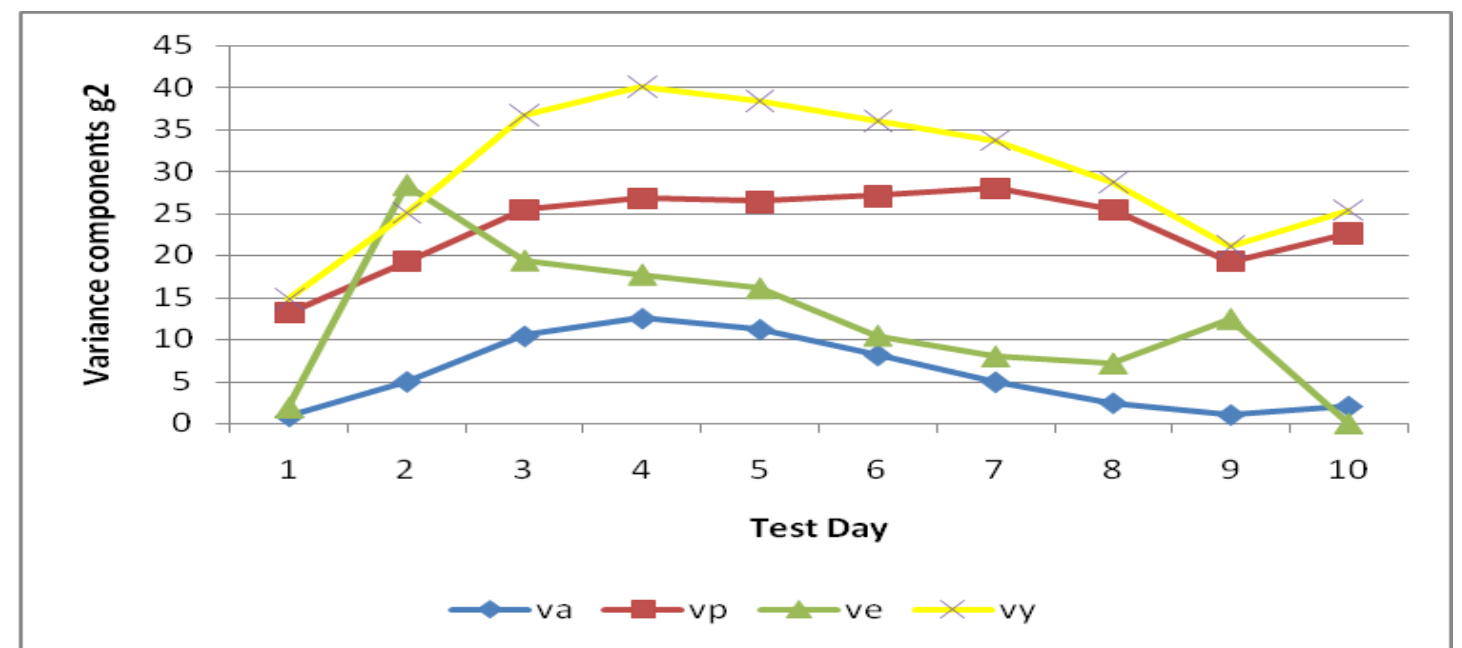

Fig. 3. Estimates of additive genetic (va), permanent environmental (vp), residual variances (ve) and phenotypic variances ( $v y$ ) for test day protein yield $(g)$ in Egyptian buffaloes

The additive genetic variance estimates showed the same trend, as the permanent environmental and phenotypic variance estimates for milk, fat and protein yields in our studies. The estimates were relatively low at early lactation; increased gradually and then decreased except at the end where the estimates increased again suddenly and the increase was very clear in the curve of permanent environmental and phenotypic variances. This trend is compatible with that obtained for the heritability. These results are in agreement with the results reported by El-Bramony et al. (2004) for buffalo. While, Aspilcueta-Borquis et al. (2010) reported higher estimates of additive genetic in all test day of lactation as well Tonhati et al. (2008) for Murrah buffalo. Madad et al. (2013) for Iranian buffalo reported a lower additive genetic. AspilcuetaBorquis et al. (2007, 2010) reported lower additive genetic variance at all test days for fat and protein yield in Murrah buffalo. Additive genetic variances for all traits are high. High variance could be due to the availability of most pedigree information. Genetic variance estimates for milk yield indicate that selection program for this trait would be effective.

Residual variance for TDMY tended to be low at both edges. Similar trends were also reported by Jamrozik and Schaeffer (1997) and Jensen et al. (2001) for cattle. However Aspilcueta-Borquis et al. (2007) for buffalo reported higher estimates in the first three months and lower estimates at the end of lactation.

\section{Hertabilities:}

Heritability estimates for TDMY at selected TD are shown graphically in Figure (4). Estimates were low at the beginning of the test day (0.049), and gradually increased, reaching the highest value at the fourth test day (0.302). Estimates decreased gradually until reached the lowest value at the tenth test day of lactation (0.057). The heritability estimates for fat and protein yields showed the same trend as for milk yield estimates. On the first day, estimates were $(0.054,0.057)$ and reached at the fourth test day 
$(0.28,0.31)$, and finally decreased at the tenth test day $(0.10,0.08)$. Similar trends were reported for milking buffaloes by Rosati and Van Vleck (2002), and El-Bramony et al. (2004).
These results differ from those of AspilcuetaBorquis et al. $(2007,2010)$ in buffalo for all traits.

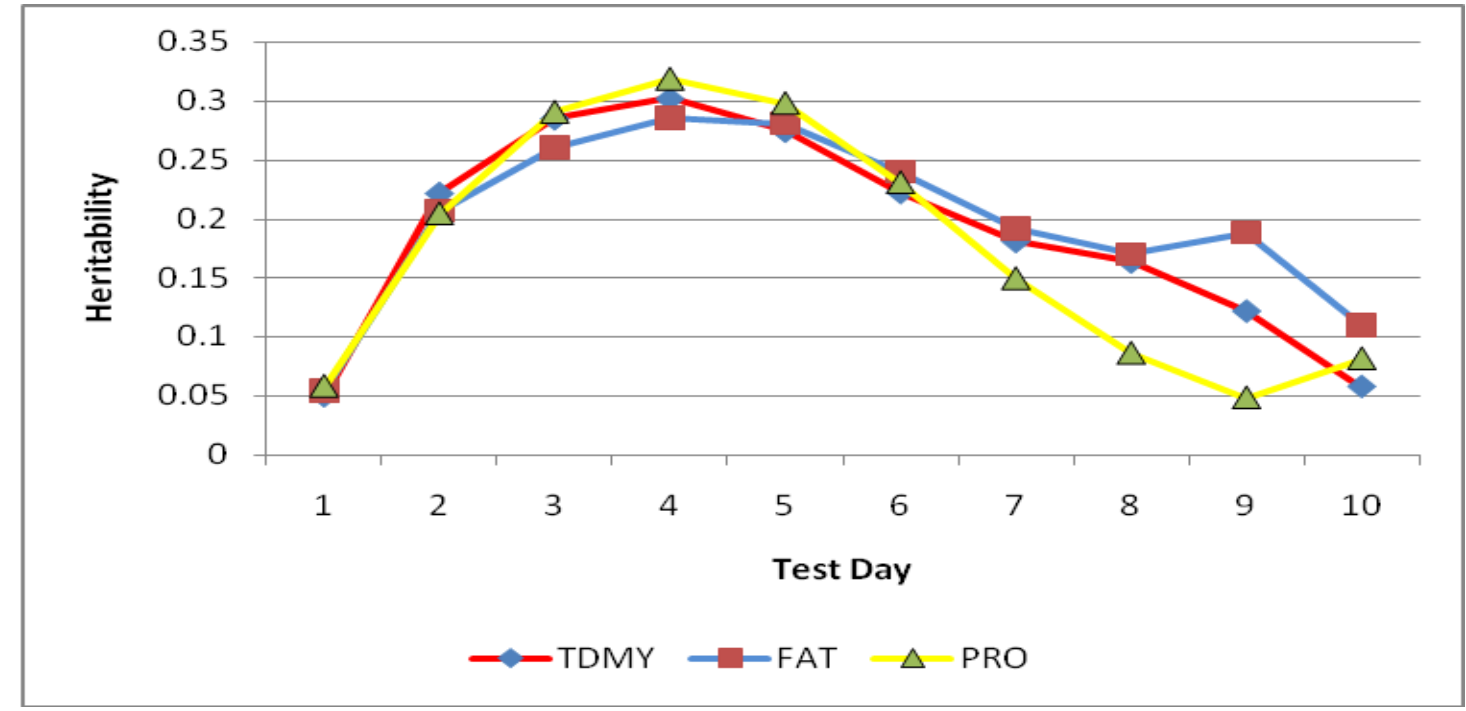

Fig. 4. Estimates of heritability at test days for daily milk, fat and protein yield in Egyptian buffaloes

In general, heritability estimates for traits had wide ranges and tended to increase toward the edges of the defined lactation trajectory. Most heritability estimates obtained by RRM were high at the edges (Jamrozik and Schaeffer, 1997) for dairy cows. Difficulties in the model in getting acceptable variances at the extremes of the lactation can be explained, in part, by the biological processes that occur at the beginning of lactation and the smaller number of records at the end Jamrozik and Schaeffer (1997), and ElSaied (2004) pointed out that these parametric functions tend to overestimate the genetic variances and underestimate the genetic correlations between milk yield at the beginning and the end of lactations. Probably this is also valid for Legendre polynomials.

\section{Predicted breeding value (PBV):}

Estimates of minimum and maximum predicted breeding values (PBV) and their accuracies for milk, fat and protein yields are given in Table (3). The PBV for test day milk, fat and protein yields ranged from -1.7 to $1.8 \mathrm{~kg}$, -
11.2 to $11.3 g$ and -6.1 to $7.1 g$, respectively. Using TD animal model methodology in cattle, Zutere (2008) found that the estimated breeding values for milk, fat and protein ranged from 1013.9 to $1965.7 \mathrm{~kg}$, from 40.75 to $93.59 \mathrm{~kg}$ and from -37.33 to $59.86 \mathrm{~kg}$, respectively. Ahmed et al. (2008) showed that the estimated breeding value for milk yield ranged from -323.40 to $345.12 \mathrm{~kg}$ in a buffalo. Abdel-Salam et al. (2009) showed that the maximum and minimum estimates of breeding values of total milk yield for commercial, experimental, flying and small holder production systems in buffalo were -377 to $368,-302$ to $297,-290$ to 190 and -76 to 96 , respectively.

The accuracies $\left({ }^{r} a \hat{a}\right)$ of minimum and maximum estimates of PBV were high in all traits (Table 3). This may be due to that estimate of heritability were highly associated with more available pedigree information for all individuals (Korhonen, 1996; Korsgaard et al., 2002).

Table 3. Minimum, maximum and ranges of predicted breeding values (PBV), predicted error variance (PEV) and accuracy of prediction $\left({ }^{r} A \hat{A}\right)$ for TD milk, fat and protein yields in

Egyptian buffaloes

\begin{tabular}{lccccccc}
\hline Trait & \multicolumn{3}{c}{ Minimum } & \multicolumn{3}{c}{ Maximum } & \multicolumn{2}{c}{ Range } \\
& PBV & PEV & $r_{A} \hat{A}$ & PBV & PEV & $r_{A} \hat{A}$ & PBV \\
\hline TDMY, kg & -1.7 & 0.22 & 0.95 & 1.8 & 0.47 & 0.98 & 3.5 \\
Fat yield, g & -11.2 & 0.22 & 0.99 & 11.3 & 0.47 & 0.995 & 22.5 \\
Protein yield, g & -6.1 & 0.22 & 0.97 & 7.1 & 0.47 & 0.99 & 13.2 \\
\hline
\end{tabular}


Genetic and Phenotypic trends:

Phenotypic and genetic trends for test day milk, fat and protein yields are shown in Figures from (5) to (10). The range in phenotypic values of year-test day milk, fat and protein yields decreased from 7.99 to $5.66 \mathrm{~kg}, 53.37$ to $35.07 \mathrm{~g}$ and 30.86 to $21.54 \mathrm{~g}$, respectively, while the respective genetic values increased from -0.22 to $0.17 \mathrm{~kg},-1.41$ to $1.36 \mathrm{~g}$ and -0.82 to $0.70 \mathrm{~g}$. These results explain the correct methodology of elimination and replacement activities. The positive genetic trends for all milk traits were a result of the good selection program. The decrease in phenotypic trend in all traits may be attributed to low nutritional level applied and management practices in different herds. Yaeghoobi et al. (2011) and Katok and Yanar (2012) found the same trend in test day milk yield in cattle. On the other hand, opposite trends showing an increase in genetic and phenotypic trends were reported by Muller and Botha (2003) for TDMY, while Khan (1998) in buffalo reported a decrease genetic and phenotypic trends in cattle. Katok and Yanar (2012), Hallowell et al. (1998) found that the genetic and phenotypic trends were increasing in milk, fat and protein yields in cattle. In the Egyptian buffalo, contrary to the present results, Khattab and Mourad (1992) reported that the phenotypic trend was increased, while, the genetic trend was decreased for total milk yield from the year of 1966 to 1987. Fooda et al. (2010) reported that the phenotypic and genetic trends for total milk yield were increased in all farms of (APRI) through the period from 1990 to 2008 .

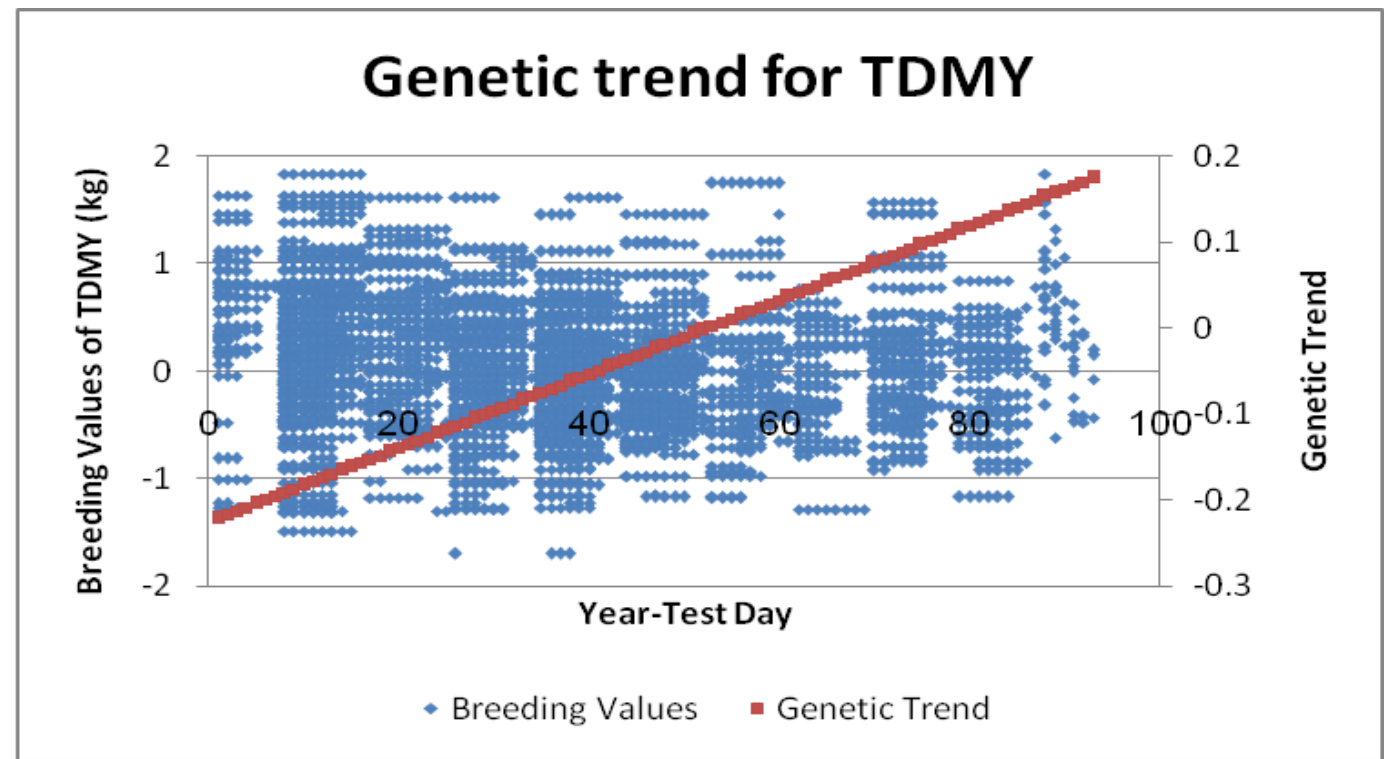

Fig. 5. Genetic trend for test day milk yield in Egyptian buffaloes

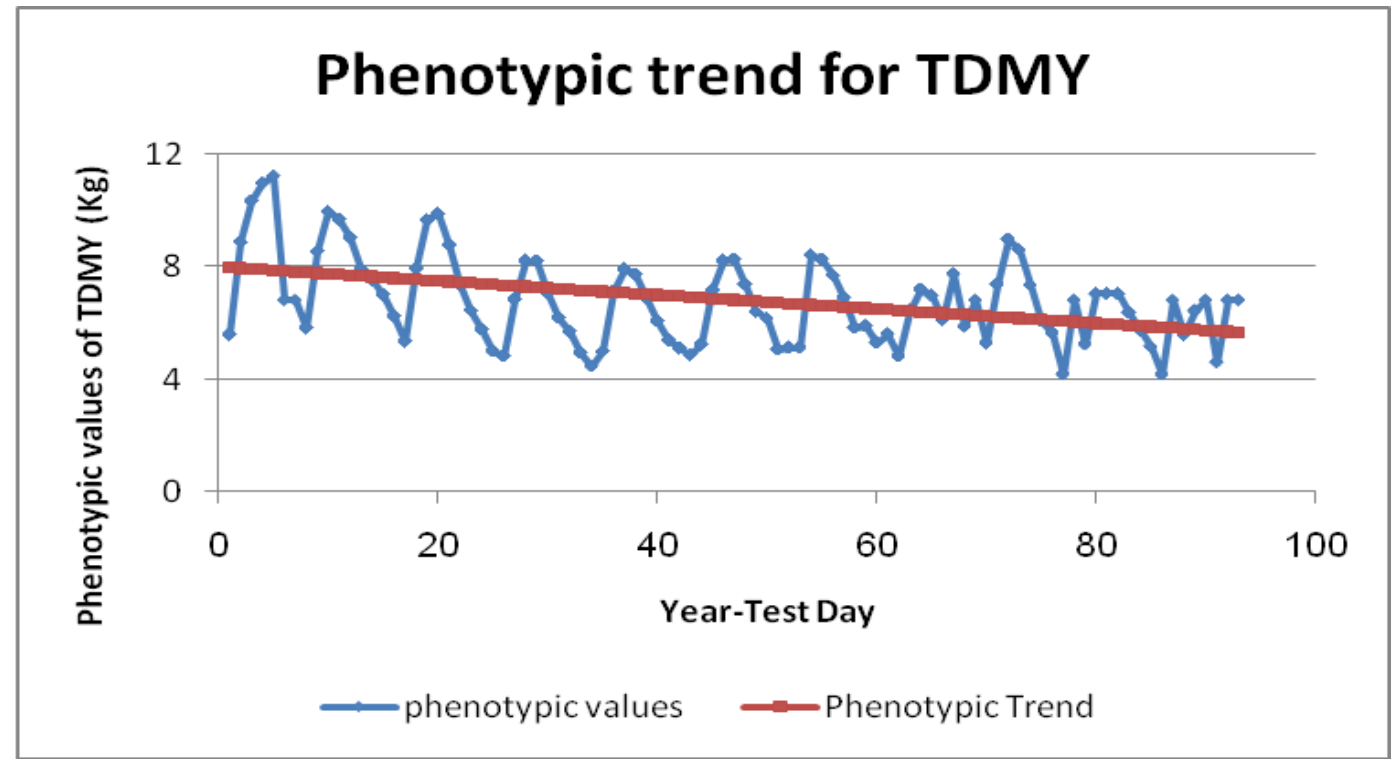

Fig. 6. Phenotypic trend for test day milk yield in Egyptian buffaloes 


\section{Genetic trend for Fat yield}

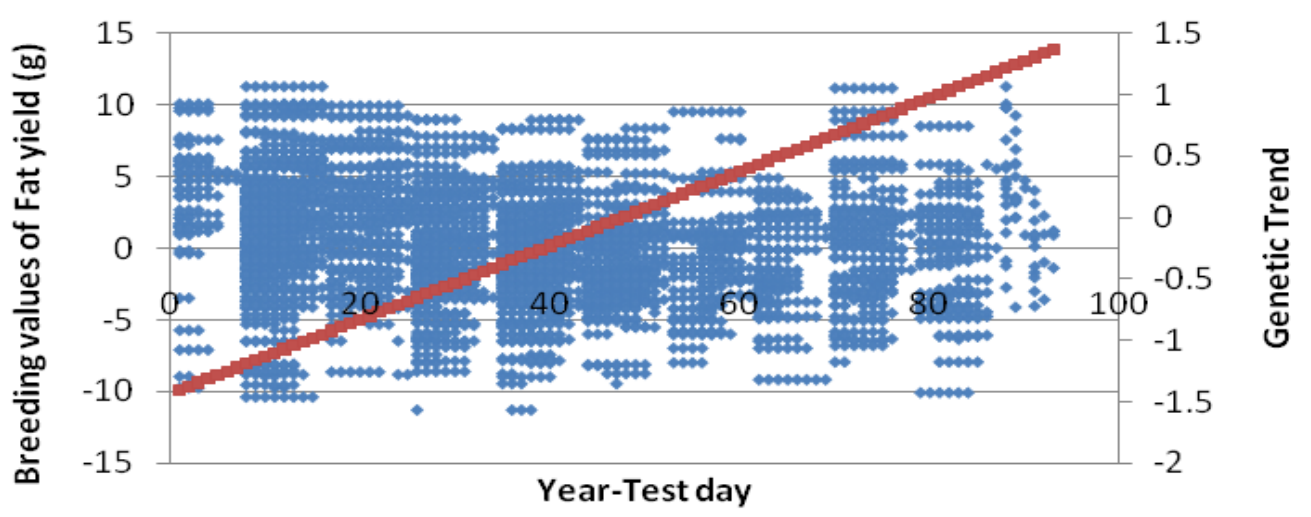

- Breeding Values - Genetic Trend

Fig. 7. Genetic trend for test day fat yield in Egyptian buffaloes

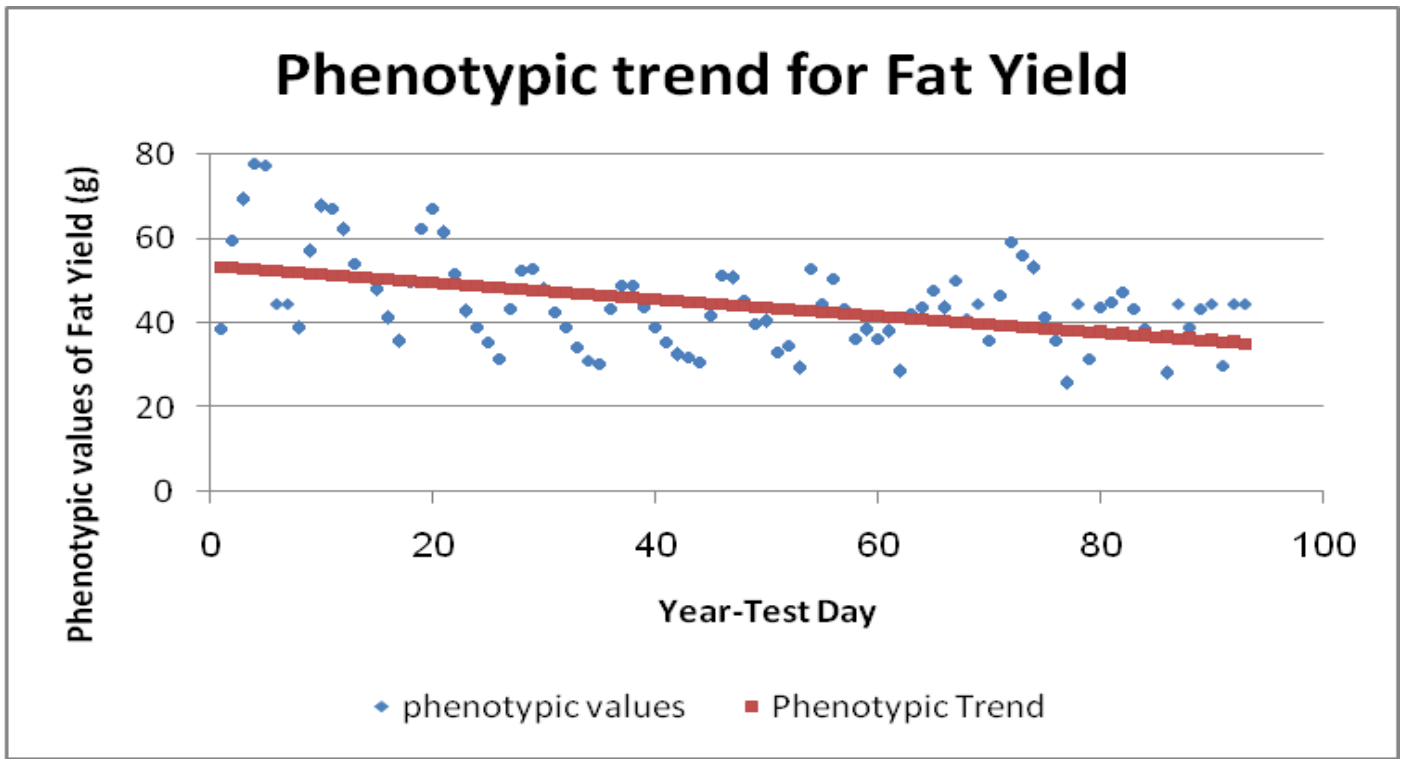

Fig. 8. Phenotypic trend for test day fat yield in Egyptian buffaloes

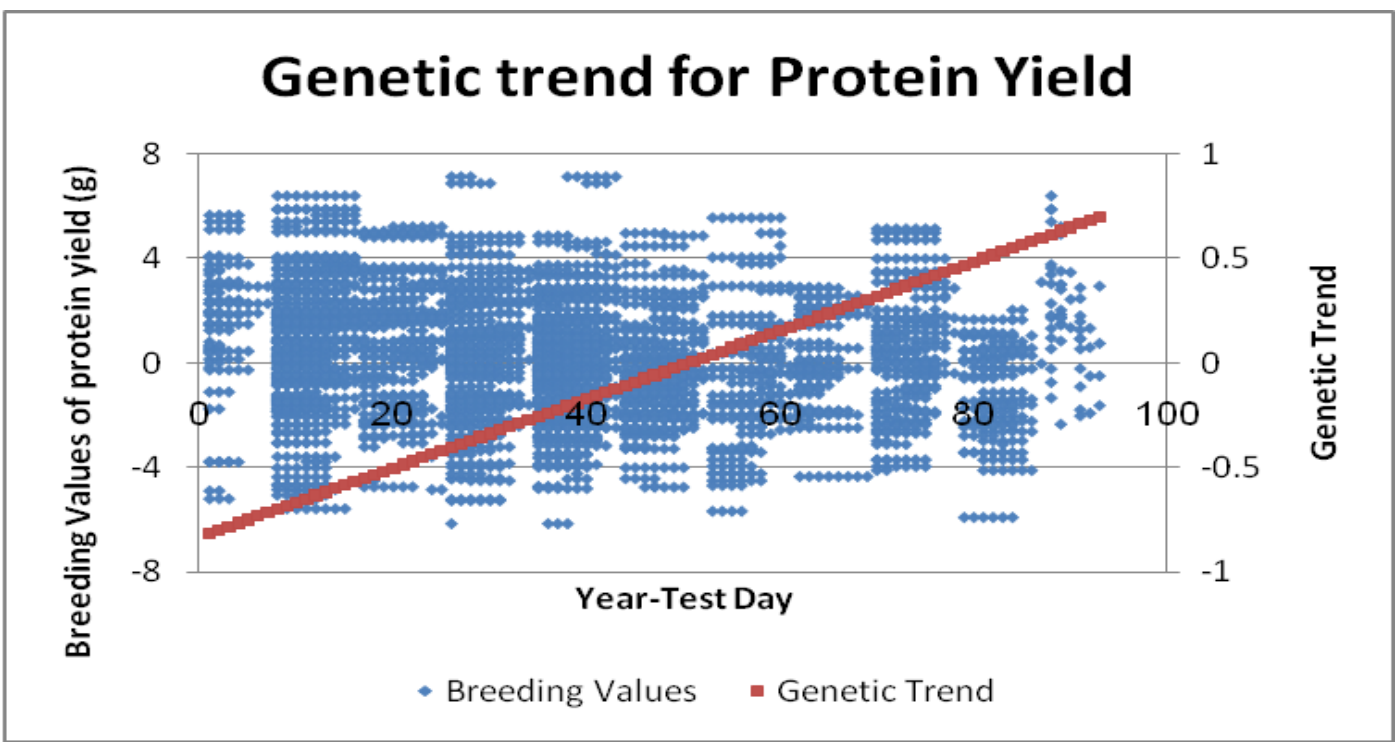

Fig. 9. Genetic trend for test day protein yield in Egyptian buffaloes 


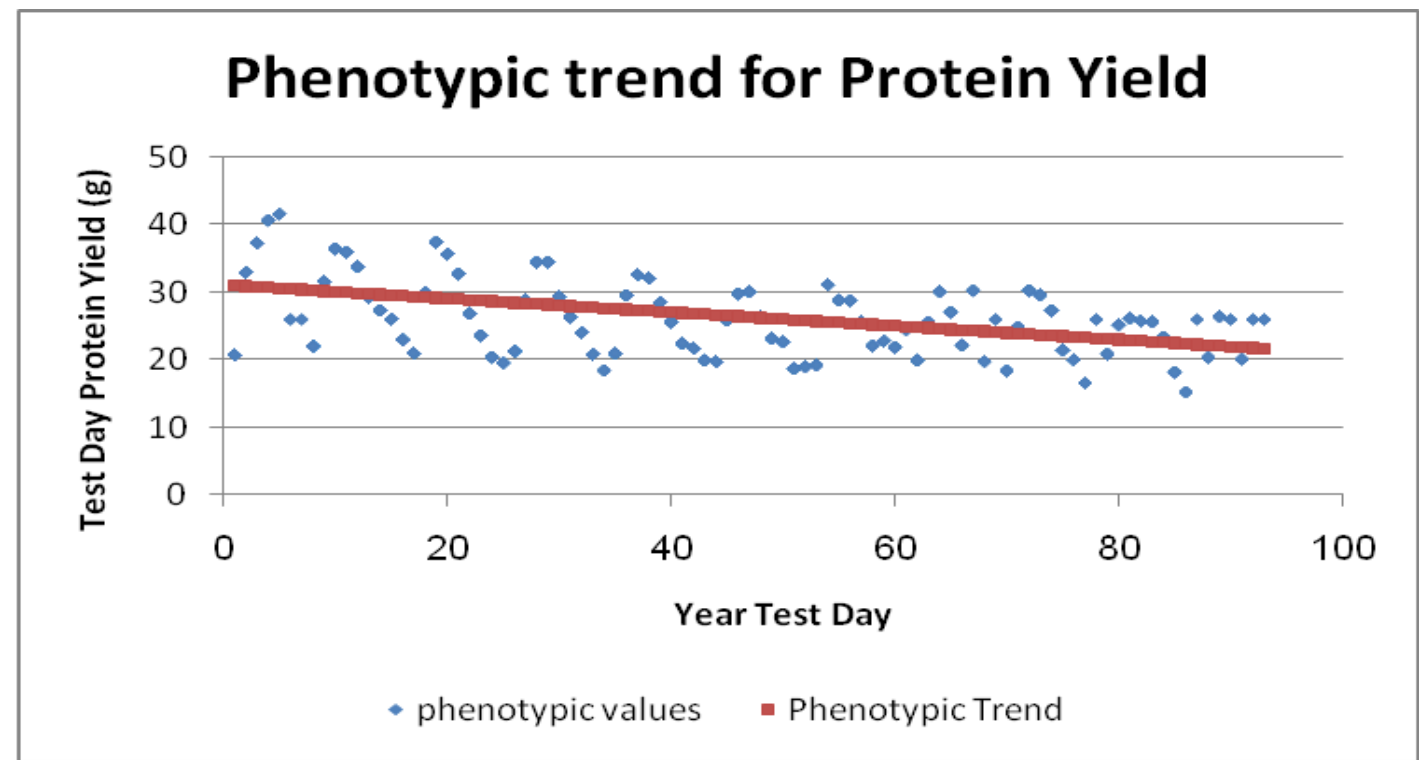

Fig.10. Phenotypic trend for test day protein yield in Egyptian buffaloes

\section{CONCLUSIONS}

1) The test-day milk yield during the first three to five months of lactation could be adopted as an early selection criterion to increase milk yield.

2) Random regression model (RRM) was considered to be efficient in detecting the fluctuations in genetic variance along the lactation period. It would permit better modeling for repeated records throughout the lactation period and could be chosen as an accurate method for predicting breeding values.

3) Improving the animal environment, particularly the nutrition and using the selection indexes could improve milk yield traits in Egyptian buffaloes.

\section{ACKNOWLEDGEMENT}

The authors are grateful to Dr. Usama M. EL-SAIED, Professor of Animal Breeding, Animal Production Research Institute, for his help and for his valuable comments in data analysis, and Dr. Victor E. Olori, Senior Geneticist (Genetic Evaluation), Aviagen Limited, New bridge UK, for his help and commenting in the estimation of predicted error variance (PEV) using Linux operating system.

\section{REFERENCES}

Abdel-Salam, S.A.M., S Abou-Bakr, M.A.M. Ibrahim, R.R. Sadek and A.S. Abdel-Aziz, 2009. Estimation of breeding values of total milk yield of Egyptian buffalo under different production systems. ICAR Technical Series, pp: 167-172.

Ahmad, M., A. Parveen, A. Gaffar, and M.M. Aziz, 2008. Estimated breeding values and genetic trend for 305-day milk yield in buffalo herd at les chak katora. Pak. J. Agri. Sci., 45(2): 212-214.

Aspilcueta-Borquis, R. B., A. Tanaka, L. Albuquerque, R. Sesana, L. Seno, A. Bignardi, H. Tonhati, 2007. Genetic parameters estimates for milk, fat and protein yield analyzed by test day models for Murrah buffaloes in Brazil. Ital. J. Anim. Sci. 6, (Suppl. 2), 368-371.

Aspilcueta-Borquis, R. B., R. C. Sesana, M. Mu.oz-Berrocal, L. O. Seno, A. B. Bignardi, L. El Faro, L. G. Albuquerque, G. M. Camargo, and H. Tonhati, 2010. Genetic parameters for milk, fat and protein yields in Murrah buffaloes (Bubalus bubalis Artiodactyla, Bovidae). Genet. Mol. Biol., 33:71-77.

Aspilcueta-Borquis, R. B., F. R. Araujo Neto, F. Baldi, D. J. Santos, L. G. Albuquerque, and H. Tonhati, 2012. Genetic parameters for test-day yield of milk, fat and protein in buffaloes estimated by random regression models. J. Dairy Res., 79:272-279.

El-Bramony, Manal M., A. A. Nigm, Kawthar A. Mourad, M.A.M. Ibrahim and U.M. El Saied, 2004.Estimation of genetic parameters for test day milk yield and somatic cell count in the first three lactations of Egyptian buffalo using random regression. 12th Scientific Conference, Egyptian Society of Animal Production. Mansoura University, Egypt, November 29-December 3, 2004. Egyptian J. Anim. Prod., 41 (Suppl. Issue): 15-31.

El-Saied, U. M., 2004. Random regression estimation of genetic parameters for milk yield and protein test day model for percentage of primiparous Frisian cows in Egypt. Egyptian J. Anim. Prod., 41 (1): 1-10. 
Fooda, T. A., A. M. Kawthar, and I. A. Gebreel, 2010.Phenotypic and genetic trends for milk production in Egyptian Buffaloes. Journal of American Science, 6(11): 143-147.

Groeneveld, E., M. Kovac, and T. Wang, 2001. PEST, Users guide and reference manual, Version 4.2.3.

Groeneveld, E., M. Kovač, and N. Mielenz, 2010.VCE 6, Users guide and reference manual, Version 6.0.2.

Hallowell, G.J., J.V.D. Westhuizen and J.B. Van Wyk, 1998. Genetic and environmental trends for first lactation milk traits in the south African Ayrshire breed. S. Afr. J. Anim. Sci., 28(1): 38-45.

Henderson, C.R., 1975. Best linear unbiased estimation and prediction under a selection model. Biometrics 31(2): 423-447.

Hossein-Zadeh, N. G., 2011. Genetic and phenotypic trends for age at first calving and milk yield and compositions in Holstein dairy cows. Archiv Tierzucht 54: 4, 338-347.

INTERBULL, 2009. Home page address: http://www-interbull.slu.se.

Jamrozik, J., and L. R. Schaeffer, 1997.Estimates of genetic parameters for a test day model with random regressions for yield traits of first lactation Holsteins. J. Dairy Sci., 80:762-770.

Jensen, J., J. Jamrozik and L. R. Schaeffer, 2001.Modelling production in all lactations in dairy cattle using random regression test day models. Book of Abstract proc. 52nd Annu.Mtg. of the EAAP. August 26-29 Budapest, 2001.

Katok, N. and M. Yanar, 2012. Milk traits and estimation of genetic, phenotypic and environmental trends for milk and milk fat yields in Holstein friesian cows. Int. J. Agric. Biol., 14: 311-314.

Kennedy, B. W. 1989. ANIMAL MODEL BLUP - Crasmus intensive graduate course. University of Guelph, Dublin.

Khan, M. S. 1998.Animal model evaluation of Nili-Ravi buffaloes. Proc. $6^{\text {th }}$ World Cong. Genet. Appl. Livest. Prod., Armidale, NSW, Australia January 11-16, 1998. Vol. 24:467470.

Khattab, A. S., and K. A. Mourad, 1992.Estimation of genetic parameters and genetic trends for some milk traits in a herd of Egyptian buffaloes. Egypt, J. Anim. Prod., 29: 173-184.

Kirkpatrick, M., D. Lofsvold, and M. Bulmer, 1990.Analysis of the inheritance, selection and evolution of growth trajectories.Genetics., 124: 979-993.

Korhonen, T., 1996.'The dairy cattle evaluation of 1996".

http://www.mloy.fi/faba/blup/blup1.html,23.01.1 977(h:14:13)(Article).
Korsgaard, I.R., A.H. Andersen and J. Jensen, 2002. Prediction error variance and expected response to selection, when selection is based on the best predictor for Gaussian and threshold characters, traits following a Posiion mixed model and survival traits. Genet. Sel. Evol. 34:307-333.

Madad, M., N. G. Hossein-Zadeh, A. A. Shadparvar and D. Kianzad, 2013. Random regression models to estimate genetic parameters for test-day milk yield and composition in Iranian buffaloes. Archiv Tierzucht 56: 27, 276-284.

Meyer, K., 1998. Modeling repeated record: Covariance function and random regression models to analyze animal breeding data. 6th WCGALP. 25:512-520. Armidale, Australia.

Muller, C.J.C., and J.A. Botha, 2003.The response to selection during first lactation on the phenotypic and genetic trends in the Elsenburg Holstein-Friesian herd. South African Journal of Animal Science , 33 (2): 111-116.

Potocnik, K., M. Stepec and J. Krsnik, 2007. Genetic trends for production and nonproduction traits in Simmental breed in Slovenia. Biotechnol. Anim. Husbandry, 23: 47-53

Ptak, E., and L.R. Schaeffer, 1993. Use of test day yields for genetic evaluation of dairy sires and cows. Livestock Prod Sci., 34:2334.

Rosati, A., and L. D. Van Vleck, 2002.Estimation of genetic parameters for milk, fat, protein and Mozzarella cheese production in Italian river buffalo population. Livest. Prod. Sci. 74:185-190.

Schaeffer, L.R., 2004. Application of random regression models in animal breeding. Livestock Production Science, 86: 35-45.

Sesana, R. C., A. B. Biganardi, R. B. AspilcuetaBorquis, L. El Faro, F. Baldi, L. G. Albuquerque, and H. Tonhati, 2010. Random regression models to estimate genetic parameters for test-day milk yield in Brazilian Murrah buffaloes. J. Anim. Breed. Genet., 127:369-376.

Silvestre, A. M., F. Petim-Batista, J. Colaço, 2005. Genetic parameter estimates of Portuguese dairy cows for milk, fat and protein using a spline test-day model. Journal of Dairy Science, 88, p.1225-1230.

Swalve, H.H., 2000. Theoretical basis and computational methods for different test-day genetic evaluation methods. J. Dairy Sci. 83:1115-1124.

Tonhati H., M. F. Cerón-Muñoz, J. A. Oliveira, L. Faro, A. L. F. Lima and L. G. Albuquerque, 2008. Test-day milk yield as a selection criterion for dairy buffaloes (BubalusbubalisArtiodactyla, Bovidae). 
Genetics and Molecular Biology, 31, 3, 674679.

Yaeghoobi, R., A. Doosti, A.M. Noorian and A.M. Bahrami, 2011.Genetic parameters and trends of milk and fat yields in Holstein's dairy cattle of west provinces of Iran. Int. J. Dairy Sci., 6: 142-149.

Zutere, R., 2008. Estimates of breeding values for dairy cattle using test-day milk yields. AGRONOMIJAS VESTIS (Latvian Journal of Agronomy), No. 10, 293-299.

\section{الإتجاهـات الوراثية و المظهريـة لمحصول يوم الاختبار من اللبن والدهن والبروتين بتطبيق نموذج الانحدار العشوائي في الجاموس المصري}

\footnotetext{
أمين محمد سعيد أمين'، ماهر حسب النبي خليل'، كوثر عبد المنعم مراد'، عزت عطا عفيفي '، محمد خيري إبراهيم׳ ا ـ معهد بحوث الإتتاج الحيوانسي ، قسم بحوث تربية الجاموس، اللدقي، الجيزة، مصر، + ـ قسم الإتتاج الحيوانسي، كلية الزراعة

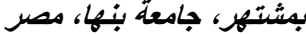

استهدفت هذه الدر اسة الكثف عن الاتجاهات الور اثية و المظهرية لمحصول اللبن و الدهن و البروتين باستخدام بيانات بوم الاختبار

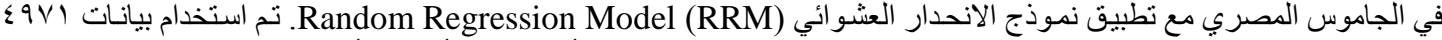

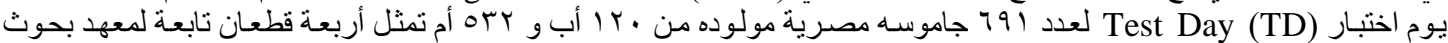

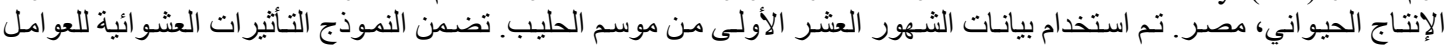

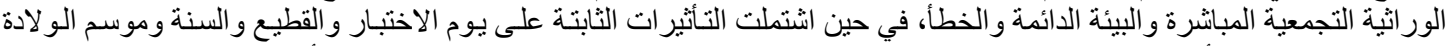

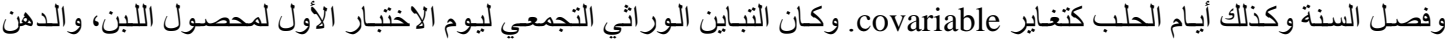

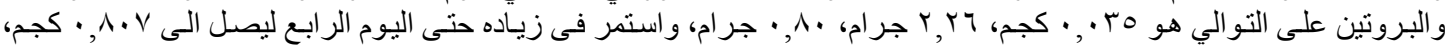

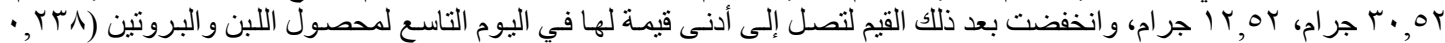

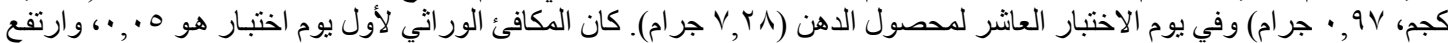

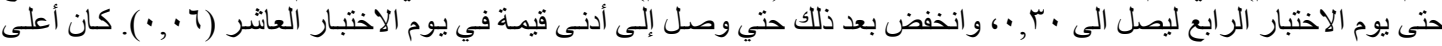

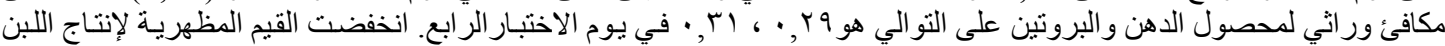

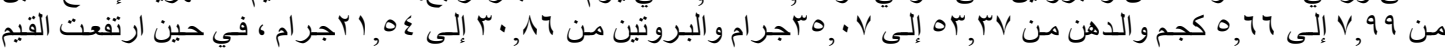

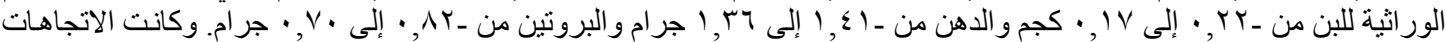

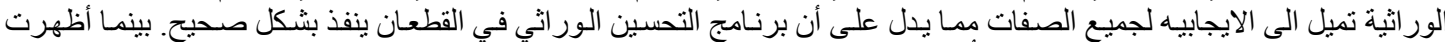

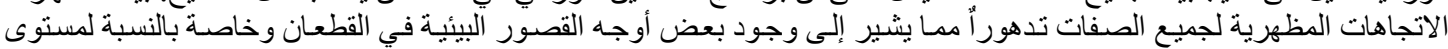

